\title{
States, anthropological complicity, and theorizing the political
}

\author{
Carole McGranahan, University of Colorado Boulder
}

Editor's preface to the Hau Book Symposium on Price, David H. 2016. Cold War anthropology: The CIA, the Pentagon, and the growth of dual-use anthropology. Durham: Duke University Press.

Cold War anthropology is a book we need. Part dogged investigation and part ethics prompt, this book uncovers histories of anthropology most scholars will wish hadn't happened or secretly wish they didn't know. Respected figures are cast in dim light. Deceased scholars are brought back to life as villains. Some are witting and some unwitting, to use David Price's terms, but all are complicit in some sense. If not complicit in willingly producing anthropological knowledge for the national security system, then a complicity in being naïve in not questioning things, in not asking who funds our grant agencies, or in not anticipating how one's research might be used against the communities in which and with whom scholars work. The sheer inevitability of avoiding the latter might debilitate an anthropologist. Most might try to do their best given these difficulties, as I did in my book on Tibet and the CIA by issuing explicit instructions on how "not" to read it (2010), while others might leave academia altogether, and some might even move from classic fieldwork to a more historical or political approach to the discipline. This is the route David Price has taken, leaving behind his earlier research in Egypt on irrigation systems $(1994,1995)$. For the last two decades, Price has dedicated his career to a tireless review of the entanglements of anthropology and the US government. The resulting trilogy of books, plus a fourth collection of essays, is a massively detailed and invaluable study and exposé of government involvement in and use of anthropology: Threatening anthropology: The FBI's surveillance and repression 
of activist anthropologists (2004), Anthropological intelligence: The deployment and neglect of American anthropology in the Second World War (2008), Weaponizing anthropology (2011), and Cold War anthropology (2016).

US military intelligence shaped anthropology during the Cold War; this is the main argument David Price makes in Cold War anthropology. Although this is a book about American anthropology and the US government, it has implications and warnings for scholarship elsewhere. Indeed, it is easy to imagine a similar book for the United Kingdom and perhaps several other states. The use-value of anthropology is at stake here: we want anthropology to be valuable; we want our books and articles to be consumed; we want our ideas and findings to be useful for others. Yet, "dual-use" in relation to the military-industrial complex is not the sort of use most anthropologists have in mind. In 2016, in the context of the continuing US-led "Global War on Terror," as well as heightened attention to racialized police violence, many anthropologists have governmental concerns parallel to those anthropologists had during the Vietnam War. "We" disassociate ourselves now from the Army's Human Terrain System just as many anthropologists did then with Project Camelot. anthropologists have long hoped their research will be deemed useful and valuable by academic colleagues and by the communities with whom they do their research, rather than simply useful to (or abused by) government or military intelligence agencies. But, is this belief too innocent? David Price suggests it is, painstakingly showing that we are still blind to the political manipulation of our research funding and topics. Yet, it is hard to make definitive assessments about scholarly complicity. In the United States, for example, should we be as suspicious of a scholar with a Peace Corps background or Fulbright funding-both US Department of State initiatives created during the Cold War-as we might be of someone with overt intelligence funding, such as a Boren Fellowship from the National Security Education Program? Reading this book, one cannot help but reflect on one's own research funding history, querying private foundation funding as well as governmental funding. Practicing an anthropology that is simultaneously aware of the interests of governments and funders, and responsive to the communities in which we work is not easy, and yet there are still paths forward. Funding of one's own research is one route, but it is not the only one. Issues of transparency and context are also key parts of conducting an ethical anthropology, as is an ethnographic commitment to the study of powerful institutions.

In this symposium on Cold War anthropology, four respondents praise the book and raise questions for it, for the field, and for Price. There is a generational element to their responses, a cache effect from research conducted over the decades, as well as a unanimous turn toward context, that is, toward providing disciplinary as well as historic and political context for the research sensibilities and protocols of any given decade. This supplements but also critiques Cold War anthropology, offering up a way of making sense of why scholars made the decisions they did with the information they had at the time. Laura Nader shares how deeply disputed and personally charged anthropological research felt for her as a graduate student at Harvard in the 1950s and then as a faculty member at Berkeley in the 1960s. In the context of the former Soviet Bloc, Katherine Verdery reflects on the gap between what scholars thought they were doing and how their scholarship might have reproduced the very discourses about state socialism they were hoping to

2016 | HAU: Journal of Ethnographic Theory 6 (2): 441-446 
combat. Given the difficulties of research behind the Iron Curtain, she asks, "is it any surprise that we were a bit lazy tracking down the exact sources of those funds and their influence on our profession?" Donna Goldstein's work in Latin America prompts her to ask how we can look back on the Chagnon-Tierney debate and especially the controversial work of biological anthropologist and geneticist James V. Neel without seeking, in her words, "historical coherence" for their acts, not so that we may absolve such scholars, but to understand and analyze. Turning to the Middle East, Ilana Feldman posits that apolitical "pure research" is not possible; instead, she shows how anthropologists are currently seeking uses for their research beyond the national security state. In addition, in ways perhaps not seen since the Vietnam War, she observes that anthropologists are now "openly debat[ing] the politics of our entanglements, to decide where we stand on those politics, and to act accordingly."

All four respondents in our symposium are scholars who "study up," to use Nader's famous term (1969). Their collective scholarship provides an ethnographic counterpart to Price's archival work, including Verdery's research on state socialism and spies (1996, 2014, and with Chari 2009), Feldman's writings on governmental security, bureaucracy, and humanitarianism (2008, 2015, and with Ticktin 2010), and Goldstein's work on nuclear scientists during the Cold War (2012, 2014, with Stawkowski 2014), and on contemporary US politics, including in this current issue of $H A U$ (with Hall and Ingram, 2016). Taken together, this is an anthropology of powerful institutions, individuals, and ideas that fleshes out needed political critiques. Several related literatures partner well with Price's scholarship, offering an ethnographic view to what goes on behind the political scenes: anthropological research with the US military (e.g., Finley 2011; Fitz-Henry 2015; Gill 2004; Gusterson 2007, 2016; Gutmann and Lutz 2010; Lutz 2002; MacLeish 2013; Wool 2015), with nuclear scientists and on security (e.g., Daniel Goldstein 2010; Gusterson 1998; Masco 2006, 2014), and on the Cold War and US empire (e.g., Coronil 1996; Ho 2004; Kim 2016; Kwon 2010; Lutz 2006; McGranahan forthcoming; McGranahan and Collins forthcoming, Schwenkel 2009; Simpson 2014; Stoler 2016; Stoler and Bond 2006; Vine 2011). It may seem redundant or obvious to cite this body of literature here, but in the context of this book symposium, this literature is at the heart of its biggest debate: the ethnographic theorizing of the political.

In her essay "Investigating anthropology's Cold War histories," Donna Goldstein critiques Price for the lack of a nuanced theoretical framework in Cold war anthropology. In his response, Price claims that "postmodern" theories cannot account for "recurrent abuses of power." However, much, if not all, of the literature cited above directly analyzes US political power through the use of various contemporary anthropological theories and approaches-discursive, ethnographic, historical, material, and political-that cannot easily be collapsed under the pejorative of "postmodernism." Instead, this is powerful, thoughtful scholarship rooted in empirical fieldwork that amplifies the history Price reveals, enabling a situating of this unsavory history as not merely in the past but as something to which we need to continually be vigilant. This is a disciplinary moment to pause and ask in the same manner as Price's book and Goldstein's response, how do we continue on? How do we continue with research that presses hard on institutions of power but that does so in ethical and uncompromised ways? Such scholarship requires not

\section{6 | HAU: Journal of Ethnographic Theory 6 (2): 441-446}


only untainted funding but also the crafting of an ethnographic and historic subjectivity for anthropologists as subjects, as well as for the subjects of anthropology. These are important questions for the discipline, for thinking about method and theory and practice, for advising and training students, and for collectively assessing where we've been and where we are going.

In that spirit, and on behalf of the $H_{A U}$ editorial team, I thank our authors for their scholarship toward these goals here and elsewhere.

\section{References}

Chari, Sharad, and Katherine Verdery. 2009. "Thinking between the posts: Postcolonialism, postsocialism, and ethnography after the Cold War." Comparative Studies in Society and History 51 (1): 6-34.

Coronil, Fernando. 1996. "Beyond occidentalism: Toward nonimperial geohistorical categories." Cultural Anthropology 11 (1): 51-87.

Feldman, Ilana. 2008. Governing Gaza: Bureaucracy, authority, and the work of rule, 19171967. Durham, NC: Duke University Press.

2015. Police encounters: Security and surveillance in Gaza under Egyptian rule. Stanford, CA: Stanford University Press.

Feldman, Ilana, and Miriam Ticktin, eds. 2010. In the name of humanity: The government of threat and care. Durham, NC: Duke University Press.

Finley, Erin. 2011. Fields of combat: Understanding PTSD among veterans of Iraq and Afghanistan. Ithaca, NY: Cornell University Press.

Fitz-Henry, Erin. 2015. US military bases and anti-military organizing: An ethnography of an Air Force base in Ecuador. New York: Palgrave Macmillan.

Gill, Lesley. 2004. The School of the Americas: Military training and political violence in the Americas. Durham, NC: Duke University Press.

Goldstein, Daniel M. 2010. “Toward a critical anthropology of security." Current Anthropologv 51 (4): 487-517.

Goldstein, Donna. 2012. “Experimantalité: Pharmaceutical insights into anthropology's epistemologically fractured self." In Medicine and the politics of knowledge, edited by Susan Levine, 118-51. Cape Town: HSRC.

—. 2014. "Toxic uncertainties of a nuclear era: Anthropology, history, memoir." American Ethnologist 41 (3): 579-84.

Goldstein, Donna M, and Magdalena E. Stawkowski. 2015. "James V. Neel and Yuri E. Dubrova: Cold war debates and the genetic effects of low-dose radiation." Journal of the History of Biology 48 (1): 67-98.

Gusterson, Hugh. 1998. Nuclear rites: A weapons laboratory at the end of the Cold War. Berkeley: University of California Press.

—. 2007. "Anthropology and militarism." Annual Review of Anthropology 36: 155-75.

—.2016. Drone: Remote control warfare. Cambridge, MA: MIT Press.

2016 | HAU: Journal of Ethnographic Theory 6 (2): 441-446 
Gutmann, Matthew, and Catherine Lutz. 2010. Breaking ranks: Iraq veterans speak out against the war. Berkeley: University of California Press.

Hall, Kira, Donna M. Goldstein, and Matthew Bruce Ingram. 2016. “The hands of Donald Trump: Entertainment, gesture, spectacle." HAU: Journal of Ethnographic Theory, this issue.

Ho, Engseng. 2004. "Empire through diasporic eyes: A view from the other boat." Comparative Studies in Society and History 46 (2): 210-46.

Kim, Eleana J. 2016. "Toward an anthropology of landmines: Rogue infrastructure and military waste in the Korean DMZ." Cultural Anthropology 31 (2): 162-87.

Kwon, Heonik. 2010. The other cold war. New York: Columbia University Press.

Lutz, Catherine. 2002. Homefront: A military city and the American twentieth century. Boston: Beacon Press.

—. 2006. "Empire is in the details." American Ethnologist 33 (4): 593-611.

MacLeish, Kenneth T. 2013. Making war at Fort Hood: Life and uncertainty in a military community. Princeton, NJ: Princeton University Press.

Masco, Joe. 2006. The nuclear borderlands: The Manhattan Project in post-Cold War New Mexico. Princeton, NJ: Princeton University Press.

2014. The theater of operations: National security affect from the Cold War to the War on Terror. Durham, NC: Duke University Press.

McGranahan, Carole. 2010. Arrested histories: Tibet, the CIA, and memories of a forgotten war. Durham, NC: Duke University Press.

McGranahan, Carole. Forthcoming. "Love and empire: Tibet, the CIA, and covert humanitarianism." In Ethnographies of U.S. empire, edited by Carole McGranahan and John F. Collins. Durham, NC: Duke University Press.

McGranahan, Carole, and John F. Collins, eds. Forthcoming. Ethnographies of U.S. empire. Durham, NC: Duke University Press.

Nader, Laura. 1969. "Up the anthropologist-Perspectives gained from studying up." In Reinventing anthropology, edited by Dell Hymes, 285-311. New York: Pantheon Press.

Price, David H. 1994. “Wittfogel's neglected hydraulic/hydroagricultural distinction.” Lournal of Anthropological Research 50 (2): 187-204.

1995. "The cultural effects of conveyance loss in gravity-fed irrigation systems." Ethnology 34 (4): 273-91.

- 2004. Threatening anthropology: The FBI's surveillance and repression of activist anthropologists. Durham, NC: Duke University Press.

- 2008. Anthropological intelligence: The deployment and neglect of American anthropology in the Second World War. Durham, NC: Duke University Press.

—. 2011. Weaponizing anthropology. Petrolia, CA: Counterpunch and AK Press.

Schwenkel, Christina. 2009. "From John McCain to Abu Ghraib: Tortured bodies and historical unaccountability of U.S. empire." American Anthropologist 111 (1): 30-42.

2016 | HAU: Journal of Ethnographic Theory 6 (2): 441-446 
Simpson, Audra. 2014. Mohawk interruptus: Political life across the borders of settler states. Durham, NC: Duke University Press.

Stoler, Ann Laura. 2016. Duress: Imperial durabilities in our times. Durham, NC: Duke University Press.

Stoler, Ann Laura, and David Bond. 2006. "Refractions off empire: Untimely comparisons in harsh times." Radical History Review 95: 93-107.

Verdery, Katherine. 1996. What was socialism, and what comes next? Princeton, NJ: Princeton University Press.

-2014. Secrets and truths: Ethnography in the archives of Romania's secret police. Budapest: Central European University Press.

Vine, David. 2011. Island of shame: The secret history of the U.S. military base on Diego Garcia. Princeton, NJ: Princeton University Press.

Wool, Zoë H. 2015. After war: The weight of life at Walter Reed. Durham, NC: Duke University Press.

Carole McGranahan

Department of Anthropology

University of Colorado Boulder

1350 Pleasant St

$233 U C B$

Boulder, CO 80309-0233

carole.mcgranahan@colorado.edu 